\title{
Using the dendro-climatological signal of urban trees as a measure of urbanization and urban heat island
}

\author{
Christoph Schneider ${ }^{1}\left[\right.$ B Burkhard Neuwirth ${ }^{2}$ (I) $\cdot$ Sebastian Schneider ${ }^{1,3} \cdot$ Daniel Balanzategui $^{1,4}{ }^{(1)}$. \\ Stefanie Elsholz $z^{1}$ Daniel Fenner ${ }^{5,6}$ (1) $\cdot$ Fred Meier $^{5}$ (D) Ingo Heinrich ${ }^{1,4,7}(\mathbb{C}$
}

Accepted: 6 December 2021 / Published online: 22 December 2021

(c) The Author(s) 2021

\begin{abstract}
Using dendroclimatological techniques this study investigates whether inner city tree-ring width (TRW) chronologies from eight tree species (ash, beech, fir, larch, lime, sessile and pedunculate oak, and pine) are suitable to examine the urban heat island of Berlin, Germany. Climate-growth relationships were analyzed for 18 sites along a gradient of increasing urbanization covering Berlin and surrounding rural areas. As a proxy for defining urban heat island intensities at each site, we applied urbanization parameters such as building fraction, impervious surfaces, and green areas. The response of TRW to monthly and seasonal air temperature, precipitation, aridity, and daily air-temperature ranges were used to identify climate-growth relationships. Trees from urban sites were found to be more sensitive to climate compared to trees in the surrounding hinterland. Ring width of the deciduous species, especially ash, beech, and oak, showed a high sensitivity to summer heat and drought at urban locations (summer signal), whereas conifer species were found suitable for the analysis of the urban heat island in late winter and early spring (winter signal).

The summer and winter signals were strongest in tree-ring chronologies when the urban heat island intensities were based on an area of about $200 \mathrm{~m}$ to $3000 \mathrm{~m}$ centered over the tree locations, and thus reflect the urban climate at the scale of city quarters. For the summer signal, the sensitivity of deciduous tree species to climate increased with urbanity.

These results indicate that urban trees can be used for climate response analyses and open new pathways to trace the evolution of urban climate change and more specifically the urban heat island, both in time and space.
\end{abstract}

Keywords Urban climate $\cdot$ Tree rings $\cdot$ Berlin $\cdot$ Urban trees $\cdot$ Correlation analysis $\cdot$ Urban growth

\section{Introduction}

Christoph Schneider

christoph.schneider@geo.hu-berlin.de

1 Geography Department, Humboldt-Universität zu Berlin, Berlin, Germany

2 DeLaWi Tree-Ring Analyses, Windeck, Germany

3 Institute of Geographical Sciences, Freie Universität Berlin, Berlin, Germany

4 Climate Dynamics and Landscape Evolution, Helmholtz Centre Potsdam, German Research Centre for Geosciences GFZ, Potsdam, Germany

5 Chair of Climatology, Institute of Ecology, Technische Universität Berlin, Berlin, Germany

6 Urban Climatology, Department of Geography, Ruhr University Bochum, Bochum, Germany

7 Department of Natural Sciences, German Archaeology Institute DAI, Berlin, Germany
The climate influenced locally by city structures is usually summarized under the term 'urban climate' (Matzarakis 2001; Oke et al. 2017). Different forms of land use within cities cause a variety of micro- and local climates (Kuttler 2004). The urban heat island (UHI) is one of the most important characteristics of urban climates (Arnfield 2003). UHI describes the phenomenon whereby urban areas typically exhibit higher air temperatures than surrounding sub-urban and rural areas, and was first recognized in the early $1800 \mathrm{~s}$ (Howard 1833). In the inner city, diurnal cycles of air temperature are different from those in the surrounding area (Oke 1982). Typically, nighttime minimum air temperatures are much higher (Matzarakis 2001; Kuttler et al. 2015). 'Trees are wonderful things' (McCarroll and Loader 2004) not only because they cool the environment (Smithers et al. 2018), but also because they deliver important ecosystem services 
such as pollution mitigation (Escobedo et al. 2011; Grote et al. 2016) and stormwater control (Berland et al. 2017). Especially, the cooling effect of urban street trees via shading and transpiration and its effects on human thermal comfort has been extensively studied (e.g., Armson et al 2013; Gillner et al. 2015; Konarska et al. 2015; Rahman et al. 2020).

In addition, spatial patterns and the temporal development of urban thermal climates at different scales have also been analysed using computer-assisted modelling (Früh et al. 2011; Schubert et al. 2012; Buttstädt and Schneider 2014) or crowdsourced data from citizen weather stations (Chapman et al. 2017; Fenner et al. 2017; Meier et al. 2017; Feichtinger et al. 2020; Venter et al. 2020). Moreover, urban tree growth has been modelled and simulated under present and future climate conditions (Broadbent et al. 2019; Buccolieri et al. 2018; Canetti et al. 2017; Rötzer et al. 2019). Long time series of urban climates are rare, and their temporal homogeneity is often limited by varying measurement techniques or locations over time. Therefore, little is known about the long-term spatiotemporal evolution of UHI as previous studies were limited to single pairs of urban and rural stations, or gridded datasets without intra-urban differentiation (Ajaaj et al. 2018; Varquez and Kanda 2018). Despite restrictions on building height and large amounts of green space, Berlin has the strongest UHI in Germany (Fenner et al. 2014; Kuttler et al. 2015). However, only few observational time series spanning climatological time periods such as 30 years or more are available and the majority of those fail to characterise the inner-city climate because they are found in open sites (i.e., inner-city airports). Thus, a comprehensive investigation regarding intra-city UHI characteristics across several decades is hampered.

Dendroclimatological studies in northeastern Germany have provided unique insight into the growth response of trees to external influences. For example, tree growth of oak (Quercus petraea (Matt.) Liebl. and Q. robur L.) and beech (Fagus sylvatica L.) show negative relationships with air temperature and positive relationships with precipitation during the summer months, which has been interpreted as drought response (Friedrichs et al. 2009a; Scharnweber et al. 2011; Fischer and Neuwirth 2013; Gillner et al. 2020). Cook et al. (2015) identified increasing drought stress for the leading tree species beech, oak, and pine (Pinus sylvestris L.) in Central European forests. In pine trees, a positive growth response to above average cold-season air temperature has been found in the temperate lowlands across northern Germany and Poland (Przybylak et al. 2005; Cedro 2007; Moir 2008; Friedrichs et al.2009a; Koprowski et al. 2012; Opała 2015; Balanzategui et al. 2018). While such dendroclimatological studies exist for most common European tree species, they have typically focused on trees growing in forest ecosystems. Studies that directly compare the climate response of trees growing in forests, rural or city environments are still rare (Finley et al. 2016; Wilde and Maxwell 2018), most likely because tree growth in urban areas is perceived to be more influenced by human activities than climatic factors. Thus, the actual climate signal is thought to be masked by many other influences and therefore challenging to isolate (Gillner et al. 2013). Nevertheless, tree-ring growth patterns in urban trees have been analysed in the German cities of Munich (Bayer et al. 2018; Moser-Reischl et al. 2019a; Stratopoulos et al. 2019), Potsdam (Gillner et al. 2020), Dresden, and Berlin (Dahlhausen et al. 2017; Gillner et al. 2013, 2014; Pretzsch et al. 2017) with hot and dry summers recognized as one of the main factors limiting radial tree growth. However, it appears that some species are capable of coping better than others, for instance in Munich, black locust (Robinia pseudoacacia L.) showed greater drought tolerance than small-leaved lime (Tilia cordata Mill.) (Moser-Reischl et al. 2019a).

For Berlin and Dresden, it has been suggested that city trees are showing signs of stress and an accelerated growth from effects of the UHI and climate change (Gillner et al. 2013, 2014; Pretzsch et al. 2017). Gillner (2012) examined the dendroclimatic signal in tree rings of urban trees in Dresden. The most important factors limiting growth identified in their study were April to July precipitation, and summer and autumn air temperature of the previous year (Gillner et al. 2013, 2014). In Berlin, Dahlhausen et al. (2017) found that in densely built-up urban areas, lime, the most commonly planted street tree in Berlin (SEN 2017), benefitted from high air temperatures and low precipitation, but not so in areas with low urban development. Furthermore, they concluded that under current climate change the lime trees investigated were expected to grow better under future climate conditions (Dahlhausen et al. 2017; Pretzsch et al. 2017).

Gillner et al. (2013) and Pretzsch et al. (2017) demonstrated that climate signals can be clearly derived from urban tree-ring series. These studies also indicated that urban trees may grow differently than rural trees, and therefore, differences in UHI conditions may be revealed based on different growth characteristics. Moser-Reischl et al. (2019b) was able to identify tree growth variations along a gradient between urban and rural sites that were affected more or less strongly by environmental pollution. Even though the study did not quantify the effect of UHI, it demonstrates that tree-ring analysis can be used to identify, compare, and exploit different sensitivities between urban and rural trees. Similar results were reported for urban tree growth in Sao Paulo, Brazil (Locosselli et al. 2019) and Melbourne, Australia (Gebert et al. 2019).

Encouraged by the already existing findings suggesting different climate-growth correlations for urban and rural trees, the overall aim of our study is to evaluate whether annual tree-ring series of urban trees bear signals suitable for the analysis of long-term temporal UHI characteristics. More specifically, does the variety of tree species commonly found growing in urban Berlin carry climate signals 
comparable to tree-ring studies from rural environments? Subsequently, we aim to verify if such climate signals depend on the degree of urbanization, and if so, whether this relationship may be exploited to retrospectively assess the spatial and temporal evolution of the UHI. Therefore, in a first step, climate-growth relationships were investigated for various tree species growing together in a large innercity park, Grünanlage Britz-Süd (GBS), in the district of Neukölln (Figs. 1 and 2). In a second step, we examined the climate-growth relationships calculated for several sites across a transect with inner-city to rural environmental site characteristics to investigate the influence of the degree of urbanization on deciduous tree growth.

\section{Methods}

\section{Study area}

The German capital, Berlin $\left(52.5^{\circ} \mathrm{N}, 13.4^{\circ} \mathrm{E}\right)$, is the country's largest city in terms of size $\left(892 \mathrm{~km}^{2}\right)$ and population (3.76 million inhabitants as of 2020). Consequently, Berlin has a pronounced UHI of $1.5 \mathrm{~K}$ in the long-term mean and more than $10 \mathrm{~K}$ under extreme conditions (Fenner et al. 2014). The city is located in the temperate lowlands without any significant heterogenous topography which might potentially cause natural climate gradients due to, for example, differences in slope angle, aspect, or tree position on ridges versus valleys. The flat character of lowland sites minimizes the effects of topography on tree growth. Hence, the general natural growth conditions are spatially homogenous and therefore the probability of finding clear tree-growth anomalies related to UHI effects is increased. The influence of urban structures on tree growth was investigated in the inner-city district of Neukölln in southeast Berlin (Fig. 2). Besides sub-urban and urban city-tree sites within the Berlin city limits, we included a number of locations in non-urban environments comprising a near-natural forest site in the Müritz National Park, and re-forested hill site in Potsdam (Fig. 1). In total, 303 trees representing eight different softand hardwood species from both rural and urban sites were analysed (Table 1).

According to the Köppen and Geiger classification the climate in the study area can be described as a marine temperate climate with continental influences $(\mathrm{Cfb} / \mathrm{Dfb}$; Kottek et al. 2006; Beck et al. 2018). According to the Berlin-Dahlem (Fig. 2) weather station, the climatology of the 1961-1990 reference period showed a pronounced seasonal cycle with a mean annual air temperature of $8.9^{\circ} \mathrm{C}$ and a mean annual precipitation sum of $589 \mathrm{~mm}$ (DWD 2019). The coldest and warmest months are January and July with mean air temperatures of $-0.4^{\circ} \mathrm{C}$ and $17.9^{\circ} \mathrm{C}$, respectively, with the majority of precipitation occurring during summer months. While the reference period suggests that the study region does not experience a distinct seasonal dry period, in recent years extended dry periods without substantial precipitation and
Fig. 1 Map of the study area in northeast Germany including Berlin metropolitan area in the southern part. Red dots are sampling sites, black circles are $2000 \mathrm{~m}$ radii and black lines denote state borders. The black rectangle denotes the subset of the Berlin metropolitan area presented in Fig. 2. The orange rectangle in the sub-figure to the right shows the location of the study area within Europe. Map projection: EPSG 3857, WGS 84, Pseudo-Mercator; Landcover and land-use derived from OpenStreetMap 2021 (https:// download.geofabrik.de/europe/ germany.html), Eurostat 2021 (https://ec.europa.eu/eurostat/ de/web/gisco/geodata/referencedata/administrative-unitsstatistical-units/countries), and ESRI Deutschland Content 2021 (https://ec.europa.eu/eurostat/ de/web/gisco/geodata/referencedata/administrative-unitsstatistical-units/countries)

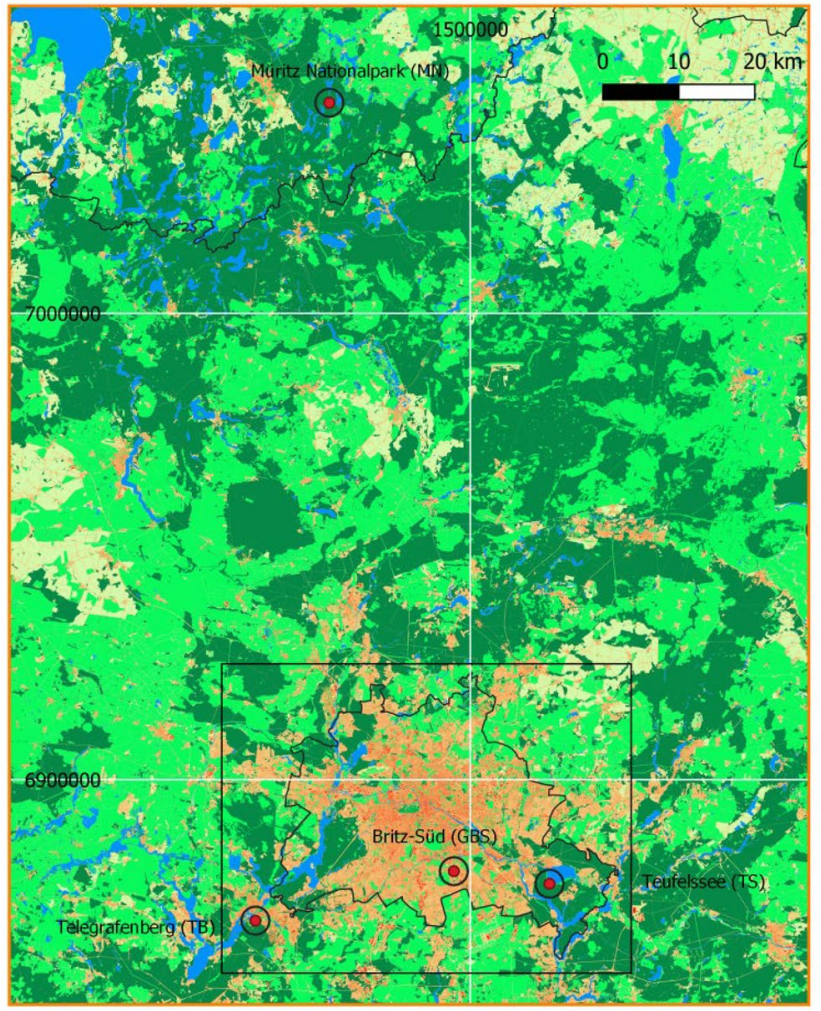

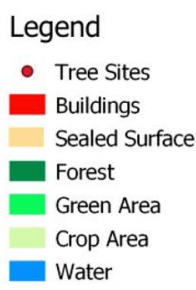




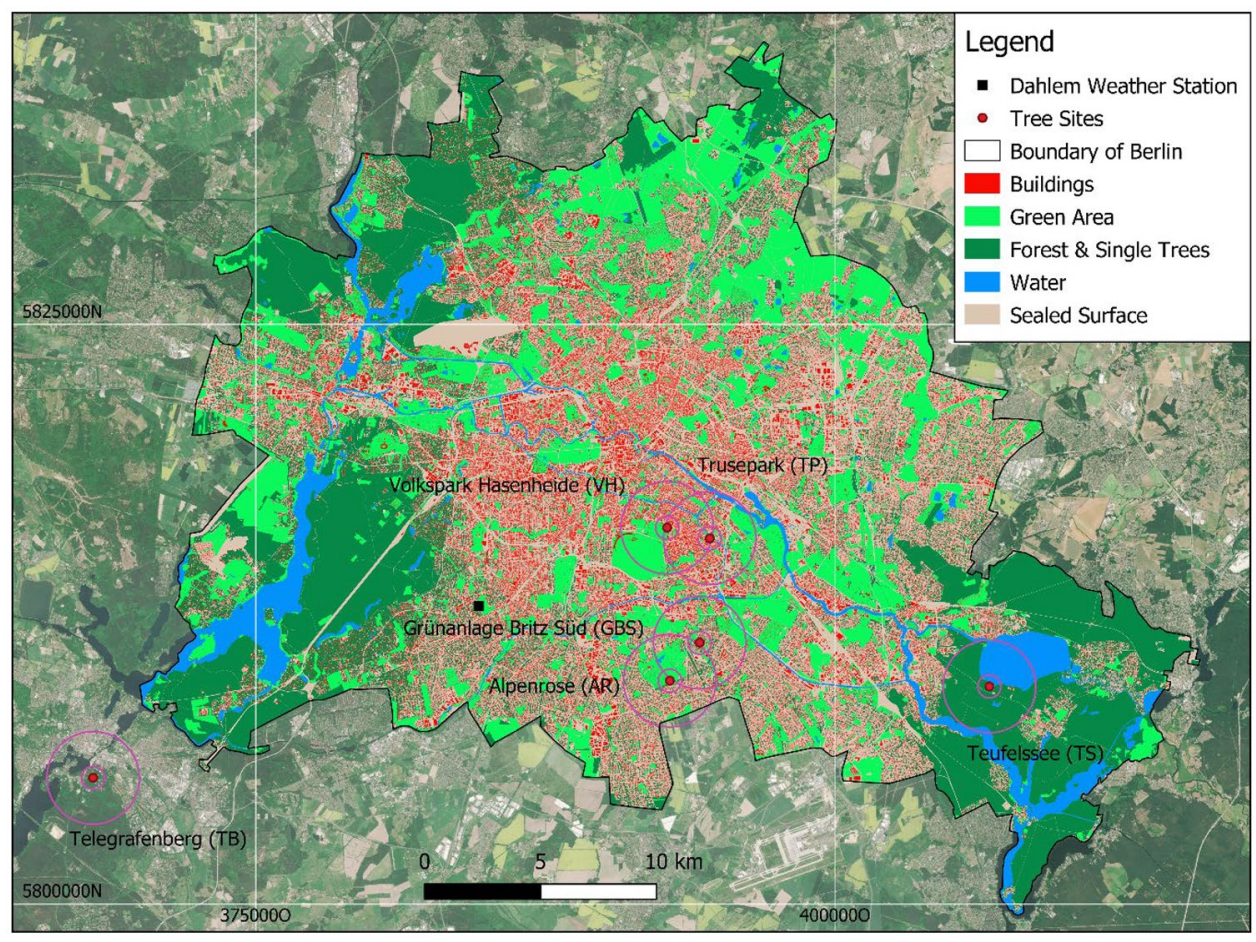

Fig. 2 Location of the inner-city and sub-urban sampling sites and land cover within the Berlin metropolitan area. Inner and outer circles surrounding each site (red dot) indicate the spatial coverage of $500 \mathrm{~m}$ and $2000 \mathrm{~m}$ radii. Other map details include the location of the Dahlem weather station (black square) and the State of Berlin boundary (black line). Map projection: EPSG:32,633, UTM 33 N, WGS 84; data sources: boundary of Berlin: Layer Bundesländer_2016_ ew, copyright GeoBasis-DE, Bundesamt für Kartographie und Geodäsie (BKG) 2018 (https://opendata-esri-de.opendata.arcgis.com/

high air temperatures have occurred several times resulting in substantial vegetation losses in urban and rural environments (Schuldt et al. 2020).

\section{Sample collection and tree-ring measurements}

Between 2014 and 2017, two 5-mm increment cores from at least twelve trees per species and site were extracted from opposing sides of mature, dominant or co-dominant individuals at $1.3 \mathrm{~m}$ above the ground. Sampling permits were obtained prior to each fieldwork campaign (see Acknowledgements), and following the protocol of Eckstein and Dujesiefken (1999) boreholes were not filled or treated after core removal. The increment cores were prepared for dating and measuring following standard dendrochronological procedures (Stokes and Smiley 1968). Tree-ring width (TRW) was measured using a LINTAB 5 system with an accuracy of $0.01 \mathrm{~mm}$, and visually and statistically cross-dated using the software TSAP-Win (Rinn 2005) and COFECHA (Holmes 1983), respectively. To enhance interannual variability and remove age- or disturbance-related growth trends, each TRW series was individually detrended by a low-pass filter using datasets), background satellite map: Sentinel 2, copyright European Union, 2018, processed by BKG (https://gdz.bkg.bund.de/index.php/ default/wms-europamosaik-aus-sentinel-2-daten-wms-sen2europe. html), city layer: Copernicus, Urban Atlas, LCLU 2018 (https://land. copernicus.eu/local/urban-atlas/urban-atlas-2018), Copernicus, Urban Atlas Street Tree Layer (STL) 2018 (https://land.copernicus.eu/local/ urban-atlas/street-tree-layer-stl-2018?tab=metadata), and OpenStreetMap2020 (https://daten.berlin.de/datensaetze/openstreetmap-daten-f\% C3\%BCr-berlin)

weighted 5-year moving averages (Speer 2010) with weights 3/9, $2 / 9$, and $1 / 9$ for the central year, the neighboring years, and the two years before and after the central year, respectively. Subsequent division of the raw curve values by the corresponding filter values results in a transformation to a high-pass filter. Finally, the detrended series of all trees from a specific site were averaged using a bi-weight robust mean (Cook 1985). Site chronologies were truncated when sample numbers fell below three trees giving a common period when all sites shared data over the interval 1962 to 2014. To evaluate the quality of the common growth signal at each site, tree-ring metrics such as mean interseries correlation (Wigley et al. 1984), Gleichläufigkeit (Schweingruber 1996), and signal strength parameter (Esper et al. 2001) were assessed for the common period. While interseries correlation (ISC) describes the similarity of the course of two time series in terms of their common variance, Gleichläufigkeit (GLK) examines the percentage of common "ups and downs" between two time series and its similarity to a sign test makes it useful for assessing similar growth reactions. The signal strength parameter (NET) combines two important growth characteristics of trees, growth level and growth response, into one parameter by 
Table 1 Description and characteristics of tree sites

\begin{tabular}{|c|c|c|c|c|c|c|c|c|c|c|c|}
\hline \multirow[t]{2}{*}{ Site } & \multicolumn{2}{|c|}{ Coordinates } & \multirow[t]{2}{*}{ Species } & \multirow[t]{2}{*}{ MSL (years) } & \multirow[t]{2}{*}{$\operatorname{AGR}(\mathbf{m m} / \mathbf{a})$} & \multirow[t]{2}{*}{ ISC } & \multirow[t]{2}{*}{ GLK } & \multirow[t]{2}{*}{ NET } & \multicolumn{3}{|c|}{ Urban Structure $500 / 2000 / 2500 \mathrm{~m}$} \\
\hline & Lon $\left({ }^{\circ} \mathbf{E}\right)$ & Lat $\left({ }^{\circ} \mathbf{N}\right)$ & & & & & & & BF (\%) & ISF (\%) & UI ( $\%)$ \\
\hline TB & 13.0603 & 52.3833 & QUPE & 224 & 1.33 & 0.67 & 0.75 & 0.32 & $0.4 / 1.0 / 2.6$ & $2.8 / 7.2 / 11.8$ & $3.2 / 8.2 / 14.4$ \\
\hline TB & 13.0603 & 52.3378 & PISY & 130 & 1.06 & 0.44 & 0.67 & 0.44 & $0.4 / 1.0 / 2.6$ & $2.8 / 7.2 / 11.8$ & $3.2 / 8.2 / 14.4$ \\
\hline TS & 13.6272 & 52.4194 & QURO & 138 & 1.56 & 0.53 & 0.68 & 0.41 & $0.2 / 0.5 / 1.3$ & $1.4 / 3.6 / 5.9$ & $1.6 / 4.1 / 7.2$ \\
\hline TS & 13.6269 & 52.4267 & QUPE & 137 & 1.91 & 0.66 & 0.73 & 0.35 & $0.2 / 0.5 / 1.3$ & $1.4 / 3.6 / 5.9$ & $1.6 / 4.1 / 7.2$ \\
\hline $\mathbf{T P}$ & 13.4478 & 52.4819 & FREX & 75 & 4.00 & 0.42 & 0.69 & 0.47 & $27.7 / 23.9 / 21.9$ & $31.8 / 29.3 / 29.0$ & $59.3 / 53.2 / 50.9$ \\
\hline GBS & 13.4428 & 52.4414 & QUPE & 60 & 3.35 & 0.72 & 0.78 & 0.29 & $12.2 / 14.5 / 14.5$ & $21.4 / 23.8 / 24,2$ & $33.6 / 38.3 / 38,7$ \\
\hline GBS & 13.4406 & 52.4422 & PISY & 59 & 3.34 & 0.60 & 0.73 & 0.37 & $12.2 / 14.5 / 14.5$ & $21.4 / 23.8 / 24,2$ & $33.6 / 38.3 / 38,7$ \\
\hline GBS & 13.4417 & 52.4419 & PSME & 61 & 3.59 & 0.63 & 0.76 & 0.33 & $12.2 / 14.5 / 14.5$ & $21.4 / 23.8 / 24,2$ & $33.6 / 38.3 / 38,7$ \\
\hline GBS & 13.4403 & 52.4431 & LADE & 60 & 3.48 & 0.63 & 0.75 & 0.41 & $12.2 / 14.5 / 14.5$ & $21.4 / 23.8 / 24,2$ & $33.6 / 38.3 / 38,7$ \\
\hline GBS & 13.4447 & 52.4394 & TICO & 63 & 2.64 & 0.54 & 0.67 & 0.49 & $12.2 / 14.5 / 14.5$ & $21.4 / 23.8 / 24,2$ & $33.6 / 38.3 / 38,7$ \\
\hline GBS & 13.4394 & 52.4439 & FASY & 67 & 4.17 & 0.54 & 0.73 & 0.40 & $12.2 / 14.5 / 14.5$ & $21.4 / 23.8 / 24,2$ & $33.6 / 38.3 / 38,7$ \\
\hline GBS & 13.4403 & 52.4436 & QURO & 59 & 3.62 & 0.72 & 0.78 & 0.30 & $12.2 / 14.5 / 14.5$ & $21.4 / 23.8 / 24,2$ & $33.6 / 38.3 / 38,7$ \\
\hline GBS & 13.4403 & 52.4439 & FREX & 64 & 4.42 & 0.64 & 0.76 & 0.35 & $12.2 / 14.5 / 14.5$ & $21.4 / 23.8 / 24,2$ & $33.6 / 38.3 / 38,7$ \\
\hline $\mathbf{A R}$ & 13.4244 & 52.4264 & QURO & 78 & 2.84 & 0.76 & 0.79 & 0.29 & $7.8 / 11.8 / 11.7$ & $11.4 / 27.8 / 32.2$ & $19.2 / 39.6 / 43.9$ \\
\hline VH1 & 13.4206 & 52.4857 & QURO & 227 & 2.57 & 0.53 & 0.67 & 0.41 & $14.4 / 21.7 / 21.7$ & $17.0 / 29.2 / 31.0$ & $31.4 / 50.9 / 52.7$ \\
\hline VH2 & 13.4206 & 52.4857 & QURO & 239 & 1.44 & 0.79 & 0.80 & 0.27 & $20.6 / 22.5 / 21.9$ & $25.5 / 29.2 / 30.8$ & $44.1 / 51.7 / 52.7$ \\
\hline MN & 13.2028 & 53.3347 & QUPE & 323 & 1.30 & 0.60 & 0.70 & 0.36 & $0.2 / 0.5 / 1.3$ & $1.4 / 3.6 / 5.9$ & $1.6 / 4.1 / 7.2$ \\
\hline MN & 13.2028 & 53.3347 & QUPE & 320 & 1.16 & 0.62 & 0.71 & 0.34 & $0.2 / 0.5 / 1.3$ & 1.4 / $3.6 / 5.9$ & $1.6 / 4.1 / 7.2$ \\
\hline
\end{tabular}

Tree-ring series in bold were used for the correlations with UI as shown in Table 2 and Figs. 6 and 7

Sites: Telegrafenberg (TB), Teufelssee (TS), Trusepark (TP), Grünanlage Britz-Süd (GBS), Alpenrose (AR) Volkspark Hasenheide (VH1), Volkspark Hasenheide Northeast (VH2), Müritz National Park (MN)

Species codes: FASY = Fagus sylvatica, FREX $=$ Fraxinus excelsior, LADE $=$ Larix decidua, $\mathrm{PSME}=$ Pseudotsuga menziesii, $\mathrm{QURO}=$ Quercus robur, QUPE $=$ Quercus petraea, TICO $=$ Tilia cordata, and PISY $=$ Pinus sylvestris

$M S L$ mean segment length (years), AGR average growth rate (mm/year), ISC interseries correlation, GLK Gleichläufigkeit, $N E T$ signal strength parameter, $B F$ building surface fraction, $I S F$ impervious surface fraction (without buildings), $U I$ urbanity index (=BF + ISF)

additively combining the variability of the time series with the GLK. According to the literature the critical thresholds are $>0.4$ for ISC, $>0.65$ for GLK, and $<0.8$ for NET. Beyond the abovementioned detrending approach no further filtering was performed to account for loss of autocorrelation as this study did not aim for reconstruction.

\section{Climate Data}

Monthly and seasonal mean air temperature (TMP), precipitation sum (PCP), aridity index (dMI) and daily temperature ranges (MTR) were obtained from the Berlin-Dahlem weather station (German Weather Service (DWD)) (Cubasch and Kadow 2011). From here onward the term 'temperature' always stands for 'air temperature'. dMI was calculated according to the equation of de Martonne (1926) and MüllerWestermeier (1999):

$d M I=\frac{P C P}{T M P+10}$.
Since daily temperature ranges are often more meaningful than absolute temperatures when considering UHI (Varquez and Kanda 2018), monthly means of daily ranges were calculated from daily temperature maxima and temperature minima. Because weather conditions of the previous year's growing season are also important for tree growth, monthly climate variables for an 18-month window from May of the year prior to tree-ring formation to current year October, as well as seasonal and annual aggregates, were used as explanatory variables in climate response analyses. Climate data can also be affected by long-term trends. However, in this study only high frequency changes were of importance. Therefore, all 108 climatic variables were indexed similarly to the tree-ring data by calculating ratios of the raw values against the five-year weighted moving averages for the period 1962 to 2014.

\section{Geographical Information System Data}

Information on land use and land cover was derived from building and vegetation heights (Environmental Atlas Berlin 2020), and water bodies from OpenStreetMap (https:// 
Fig. 3 Urbanity Index classification for Volkspark Hasenheide $(\mathrm{VH})$ for a radius up to $3000 \mathrm{~m}$ from the sampling location. Markings for urban structural elements shown as different colours for building and vegetation heights, as well as water and sealed areas are shown in the legend

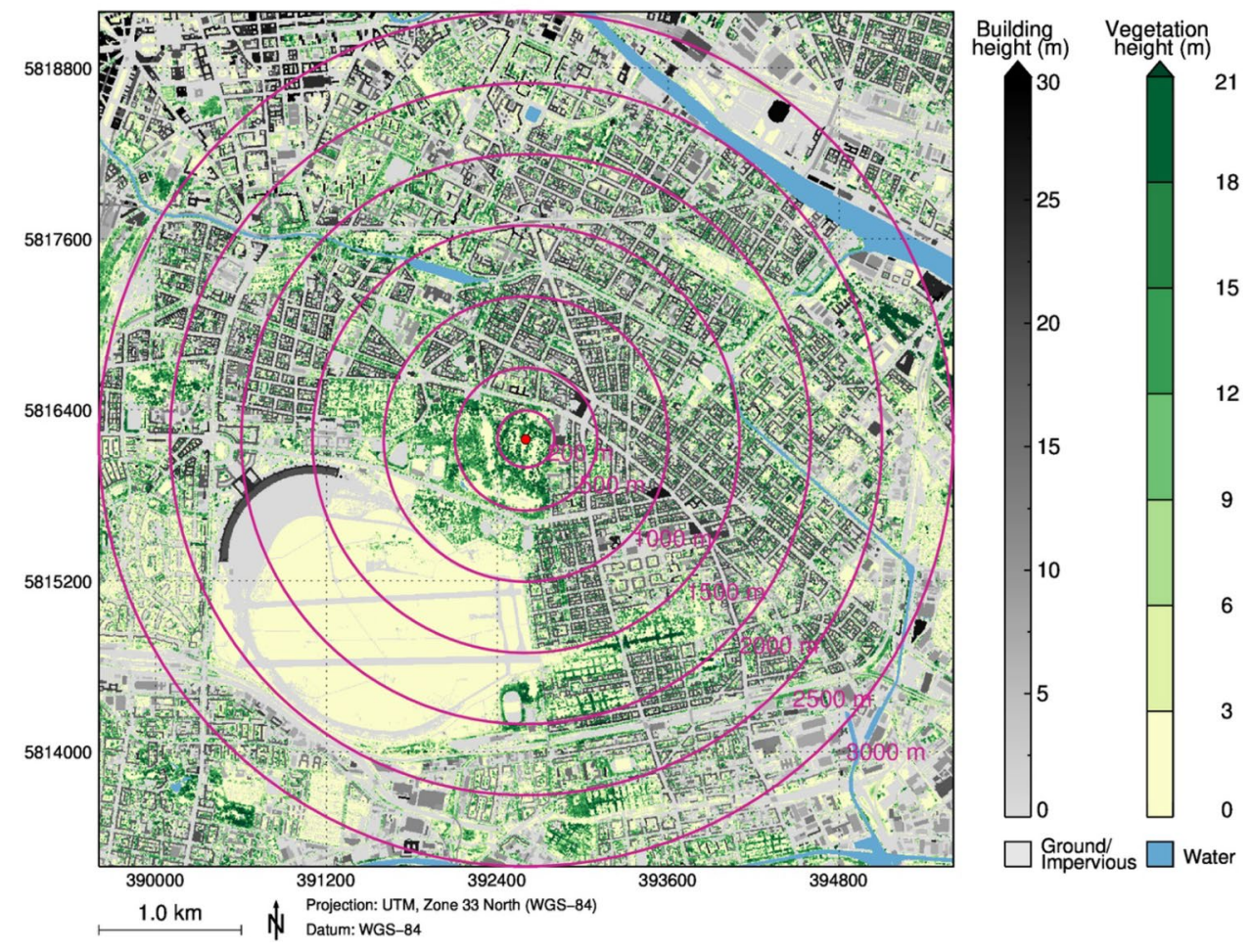

daten.berlin.de/datensaetze/openstreetmap-daten-f\%C3\% $\mathrm{BCr}$-berlin). The data was processed on a grid with a spatial resolution of $1 \mathrm{~m} \times 1 \mathrm{~m}$ for the administrative area of Berlin. Vegetation above buildings and water were masked out. For seven different radii, ranging from 200 to $3000 \mathrm{~m}$ (Table 1), the share of building (BF), vegetation, and water surface were determined for all tree-ring sampling sites. The proportion of impervious surfaces around each site (ISF, excluding buildings) was then determined as the residual between $100 \%$ and the sum of the three other surface types. An urbanity index (UI) per radius was additionally calculated as $\mathrm{UI}=\mathrm{BF}+\mathrm{ISF}$ and to illustrate this procedure Fig. 3 presents the urbanity situation for the site Volkspark Hasenheide ( $\mathrm{VH})$. Building and vegetation heights used in this study reflect the situation for the years 2009 and 2010. For the Alpenrose (AP) site, a fraction of 5\% (2000 m radius) to $15 \%$ (3000 $\mathrm{m}$ radius) was not considered in the analysis due to the limited availability of land-use and landcover data. Similarly, for the Potsdam Telegrafenberg and Müritz National Park sites, no high-resolution land-use data was available. Therefore, the BF and ISF values were estimated from topographic information for these sites. As a best guess for the different radii, the same UI values were assigned to the Müritz National Park (MNP) site as were calculated for the Teufelssee site (TS). These two locations are similar due to their low building and sealing percentages (Fig. 1). For the Potsdam Telegrafenberg site (TEL), twice the BF and ISF values of the Teufelssee site (TS) were assumed, as this site is also located in a forest, but close to the city centre and adjacent to several large buildings associated with a nearby science park.

\section{Statistical analysis}

Mean tree-ring chronologies for each site and species were explored for possible climate signals using climate-growth analysis whereby monthly and seasonal aggregates of the four climate variables PCP, TMP, dMI, and MTR were correlated with individual site chronologies (Fritts 1976; Cook and Kairiukstis 1990). The analysis used tree-ring and climate records covering the common interval 1962 to 2014 to calculate the Pearson coefficient of correlation (r) that gives the direction and strength of the climate-growth relationships. For the twelve sites with deciduous trees, the correlation coefficients were then regressed against site-specific UI variables derived from land-use and land cover parameters. In order to differentiate UHI signals, the UI variables were calculated for areas of different sizes centered over the tree sites (the coverage of seven different radii expanding from 200 to $3000 \mathrm{~m}$ ). The correlation coefficient was determined significant if $p<0.05$ according to F-test statistics. 


\section{Results}

\section{Trees growth characteristics}

Growth patterns of eight different species growing in a large inner-city park with relatively homogenous climatic conditions, were compared. The average growth rate of the trees for the majority of tree species ranged between 3.3 and $4.4 \mathrm{~mm}$ per year (Table 1), exhibiting uniform and high growth levels. Only lime showed smaller annual growth amounts averaging $2.6 \mathrm{~mm}$ each year. Regardless of species, site chronologies of radial growth (Fig. 4A) demonstrated a common long-term growth trend characterized by decreasing ring-widths since the late 1960 onwards. This trend was weaker for coniferous species that showed lower growth rates in the juvenile phase compared to hardwood species (Fig. 4A).

When comparing growth rates between urban and rural sites (Fig. 4B), urban trees consistently showed growth rates of 1 to $2 \mathrm{~mm} /$ year higher than rural trees over the common period 1962 to 2014. It has to be taken into account that the trees of the rural sites are older (up to 240 years) than most of the trees at the urban sites which were mainly planted in the second half of the twentieth century (Table 1) and are therefore exhibiting higher levels of growth. However, all site chronologies shared similar high-frequency variations, despite the different growth levels and different growth trends. This is particularly evident when comparing the indexed time series, i.e. those with standardized growth levels and adjusted for age trends (Fig. 4C), and corroborates the influence of one common external growth factor such as climate. Further, some tree sites are located closer to the weather station Berlin-Dahlem than others. Therefore, to check the influence of distance between tree sites and weather station, tree sites were correlated with four different Berlin and Potsdam weather-station time series. Correlation coefficients for the same tree sites with the four weather stations varied minimally and insignificantly (not shown). This finding is consistent with the notion that the regional climate is fairly homogenous outside the urban areas, and that climategrowth relations overall are relatively consistent across northeastern Germany and surrounding lowlands (Balanzategui et al 2018; Scharnweber et al. 2019; Harvey et al. 2020).

\section{Climate-growth response of Berlin city trees}

Monthly and seasonal climate-growth responses of the eight tree species growing at GBS demonstrated a variety of statistically significant correlations (Fig. 5). Depending on the species, either summer or winter conditions were found to be the most important factors influencing radial growth in the
Fig. 4 Comparison of tree-ring time series; A raw tree-ring widths (TRW) of deciduous species (grey) and coniferous species (black) growing at the inner-city site Grünanlage Britz-Süd (GBS). Average growth of deciduous species is shown as dashed bold line and of conifer species as solid bold black line; $\mathbf{B}$ raw treering width (TRW) site chronologies of deciduous trees across the rural-urban transect. Urban sites are shown in regular grey and rural sites in regular black lines; $\mathbf{C}$ indexed tree-ring time series of all investigated sites and species. In both, $\mathbf{B}$ and $\mathbf{C}$, averages of urban sites are shown by the dashed bold lines and rural sites by the solid bold black lines
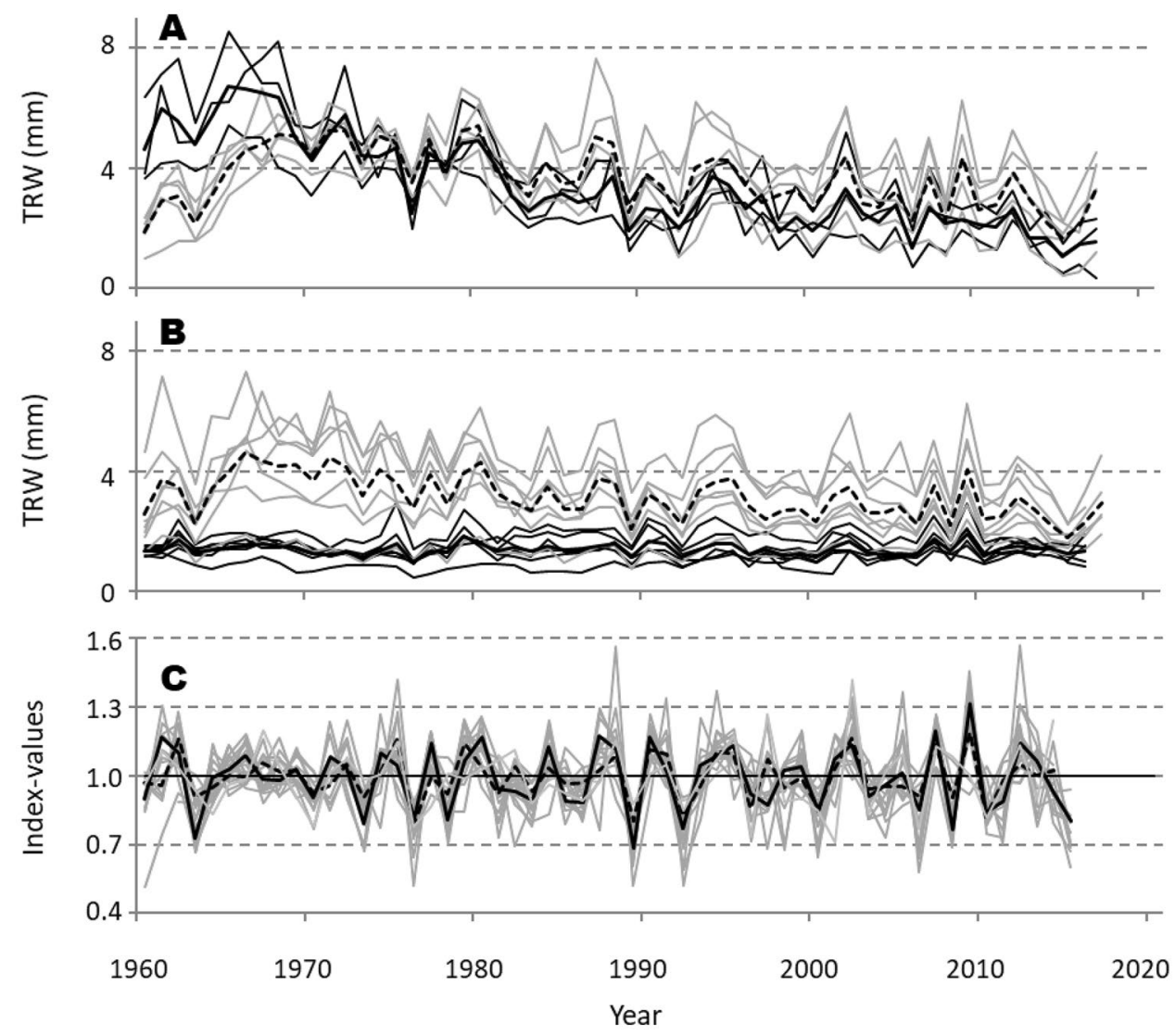
Fig. 5 Climate-response between tree-ring width chronologies of eight tree species to monthly and seasonal climate parameters from the inner-city site Grünanlage Britz-Süd (GBS). A air temperature (TMP), B precipitation (PCP), $\mathbf{C}$ aridity index (dMI), and $\mathbf{D}$, daytime/nighttime temperature range (MTR). Correlations (r) were calculated for the common period 1962 to 2014. Coniferous trees (PISY, PSME, LADE) are shown in blue colours and deciduous trees (TICO, FASY, QURO, QUPE, FREX) in yellow to red. X-axis labels with lower case prefix, $p$, indicate correlation with the preceding year. Horizontal black lines indicate significance levels at $p<0.05$ (dashed) and $p<0.01$ (solid)

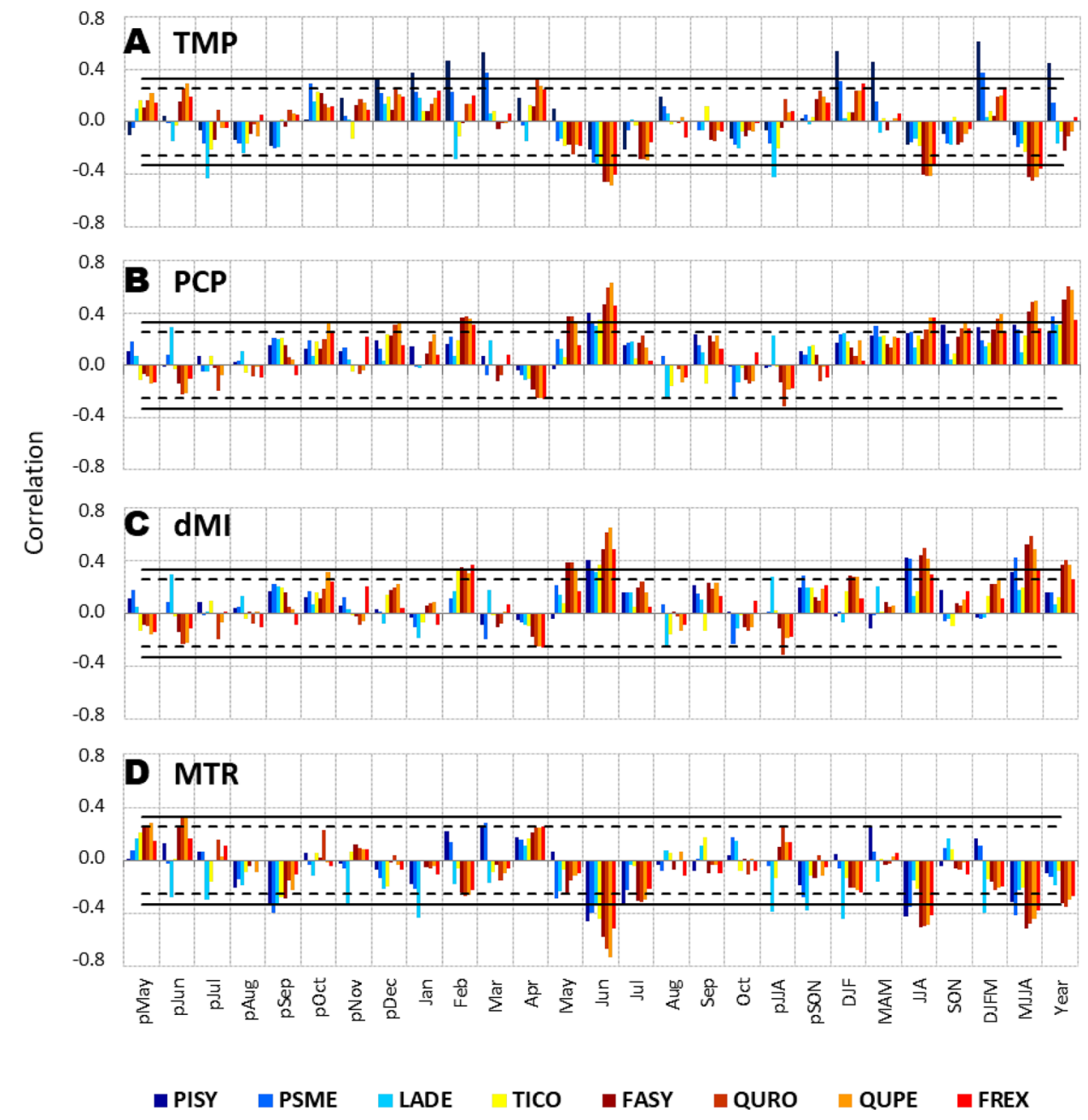

city trees. Significant correlations were found between winter temperature and the conifers, especially pine, whereas a summer signal was characteristic for the climate response of most deciduous species. In contrast, lime correlated poorly with all climate variables. Besides larch which contained a significantly negative temperature signal in July of the year before ring formation, previous year conditions seem to play only a minor role for tree-ring growth of urban trees in Berlin.

While the winter signal was characterized by a consistent positive relationship between tree-ring width and temperature from December to March (Fig. 5A), in summer, negative correlations with temperature (Fig. 5A) and positive correlations with precipitation (Fig. 5B) was the general response pattern. The impact of temperature and precipitation on tree-ring width was more apparent when considering dMI to explain radial growth (Fig. 5C), with strongest correlations in June and extended summer, May to August (MJJA) ( $\mathrm{r}=0.60$ to $0.65)$. Overall, city oak showed the highest sensitivity to arid conditions in June. Even higher correlations were observed for MTR compared to dMI. While generally in summer the correlations were around $r=-0.5$, the highest correlation was found with June and reached $r=-0.73$ (Fig. 5D).

\section{Impact of UI on oak and ash growth}

Correlations between the values of UI and the strength of the climate-growth relationships were calculated for different radii ranging from 200 to $3000 \mathrm{~m}$ around tree sites in order to constrain the area for calculating the urban surface parameters (UI values) potentially influencing tree growth (Table 2; Fig. 6). Each coefficient of determination $\left(\mathrm{R}^{2}\right)$ refers to the correlation between one data set of twelve pairs of UI variables and climate-growth signals from the oak and ash tree sites. The results show different radii within which the correlation between urbanity and climate signals derived from annual rings reaches its maximum (bold values in Table 2). While for the summer season, the maximum for dMI is reached for $2000 \mathrm{~m}$ around the tree sites, TMP and MTR have higher values for smaller radii and thus smaller areas. For JJA as well as MJJA, the strongest signals are reached within a radius of $500 \mathrm{~m}$. $\mathrm{R}^{2}$ for June MTR, however, reached their 
Table 2 Coefficients of determination $\left(\mathrm{R}^{2}\right)$ derived from linear regression models using variables of Urbanity Index to predict the strength of the climate response (coefficient of correlation) of hard- wood tree sites along rural-to-urban transect for selected climate parameters and seasonal periods. $\mathrm{R}^{2}$ below 0.3 are not shown. For each parameter, the highest value in each column is presented bold

\begin{tabular}{c|ccc|ccc|ccc|ccc}
$\begin{array}{c}\text { UI } \\
\text { radii } \\
(\mathbf{m})\end{array}$ & \multicolumn{3}{|c|}{ TMP } & \multicolumn{3}{|c|}{ PCP } & \multicolumn{3}{c}{ MTR } & \multicolumn{3}{c}{ dMI } \\
\hline $\mathbf{2 0 0}$ & - & JJA & MJJA & JUN & JJA & MJJA & JUN & JJA & MJJA & JUN & JJA & MJJA \\
$\mathbf{5 0 0}$ & - & $\mathbf{0 . 6 7}$ & $\mathbf{0 . 6 4}$ & 0.62 & - & - & 0.52 & $\mathbf{0 . 6 6}$ & $\mathbf{0 . 7 6}$ & 0.61 & 0.62 & 0.68 \\
$\mathbf{1 0 0 0}$ & - & 0.58 & 0.56 & 0.70 & - & - & 0.55 & 0.58 & 0.71 & 0.68 & 0.59 & 0.68 \\
$\mathbf{1 5 0 0}$ & - & 0.59 & 0.58 & 0.72 & - & - & 0.58 & 0.60 & 0.72 & 0.69 & 0.62 & 0.71 \\
$\mathbf{2 0 0 0}$ & - & 0.60 & 0.59 & 0.73 & - & - & 0.60 & 0.62 & 0.74 & $\mathbf{0 . 6 9}$ & $\mathbf{0 . 6 6}$ & $\mathbf{0 . 7 5}$ \\
$\mathbf{2 5 0 0}$ & - & 0.57 & 0.57 & $\mathbf{0 . 7 3}$ & - & - & 0.60 & 0.60 & 0.72 & 0.69 & 0.64 & 0.74 \\
$\mathbf{3 0 0 0}$ & - & 0.55 & 0.56 & 0.71 & - & - & $\mathbf{0 . 6 1}$ & 0.59 & 0.71 & 0.68 & 0.62 & 0.74
\end{tabular}

maximum for radii above $2500 \mathrm{~m}$. In summary, the best fitting regression models were found with area sizes of $500 \mathrm{~m}$ radii for temperature-based indices, and at $2000 \mathrm{~m}$ for aridity-based indices. The values for the relationships of urbanity to climate signals for June temperature (TMP-JUN) as well as summer precipitation (PCP-JJJA and PCP-MJJA) were not found to be significant and therefore not considered any further. The relationship between the climate-growth correlations and the degree of urbanity at the respective tree locations strongly suggests a near linear intensification of the climate-growth signal with increasing urbanity (Fig. 7).

For all investigated relationships, at least $60 \%$ of the variance of the climate-growth correlations could be explained by UI. The strongest relationships were found for dMI $\left(\mathrm{R}^{2}=0.75\right)$ and MTR $\left(\mathrm{R}^{2}=0.76\right)$ during the extended MJJA summer period. However, it should be pointed out that for these two relationships, significant climate-growth correlations were not available for all locations. In rural areas, no significant correlations were found for dMI, and only at some locations did MTR show a significant, although weak, impact on tree growth. Where tree growth was positively influenced by June precipitation, very strong correlations with UI were also found $\left(R^{2}=0.73\right)$. This also applied to the June values of dMI and MTR (marginally weaker with $\mathrm{R}^{2}=0.69$ for $\mathrm{dMI}$ and $\mathrm{R}^{2}=0.60$ for MTR). Also, for the summer temperature correlations (TMP-JJA and TMP-MJJA) the explained dependency on urbanity was around $65 \%$.

\section{Discussion}

This study presented climate-growth analyses of 303 trees across 18 locations that encompass a diverse range of Berlin's urban, sub-urban and rural environments. The climate signals of eight tree species were determined to identify whether
Fig. 6 Coefficients of determination $\left(\mathrm{R}^{2}\right)$ between r-values (calculated between site mean curves of the twelve deciduous tree locations and air temperature (TMP) and precipitation (PCP) time series, ariditiy index (dMI) and monthly temperature range (MTR) for June (JUN) and extended summer (MJJA)) and the corresponding twelve urbanity indices (UI) determined for areal buffers with radii ranging from 200 to $3000 \mathrm{~m}$ centered over the sampling sites

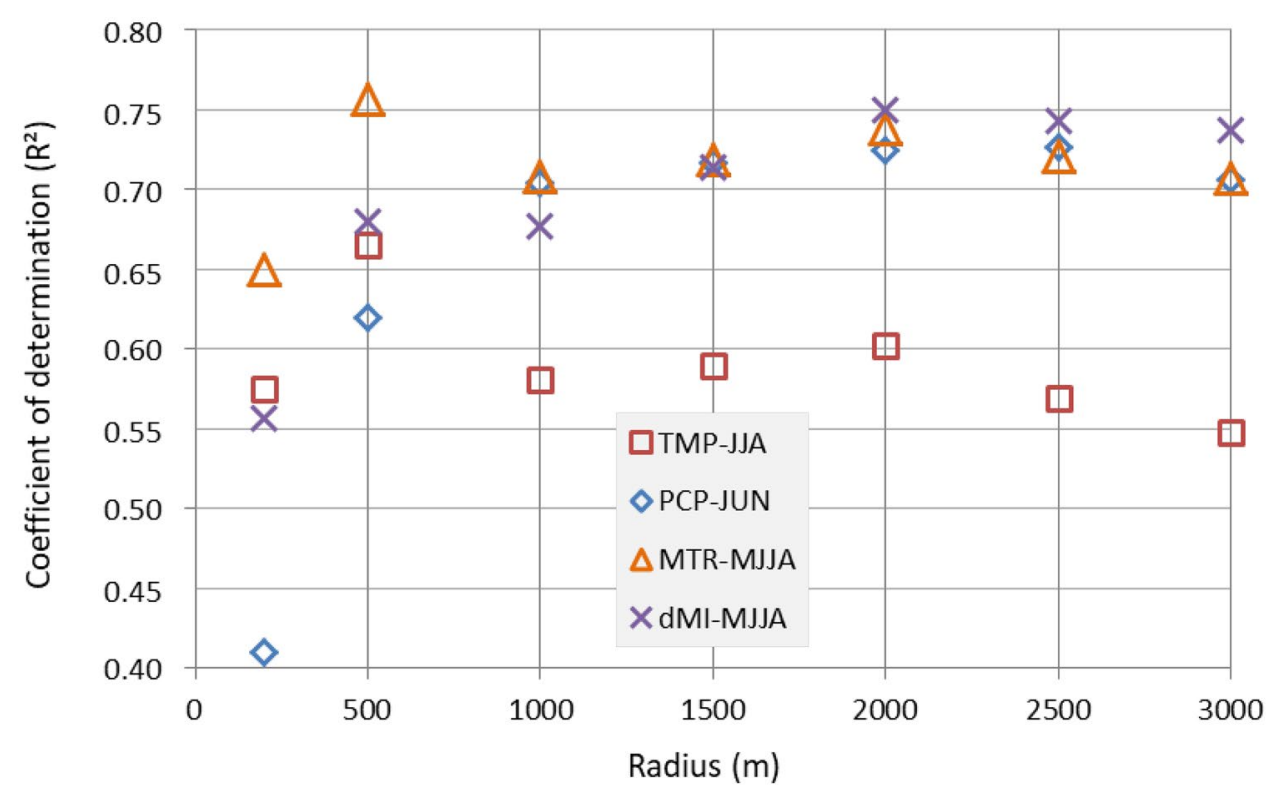




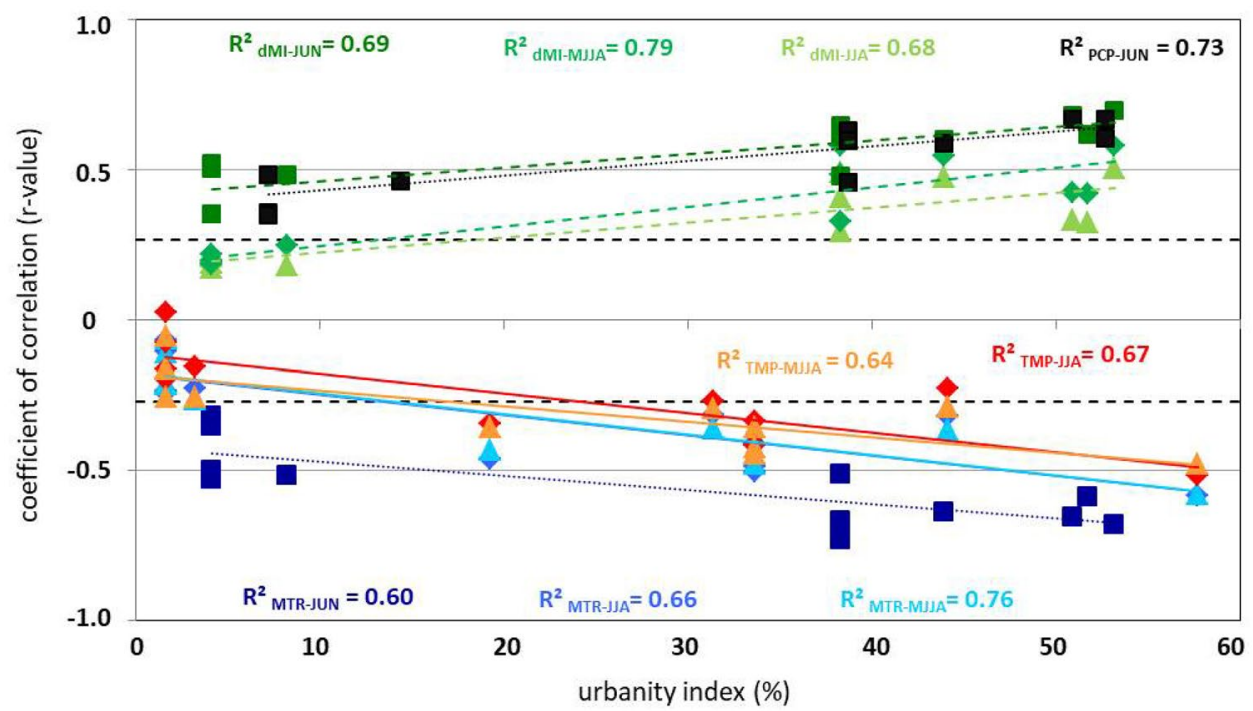

Fig. 7 Scatter plots with linear regressions and coefficients of determination between twelve r-values, calculated between indexed site mean curves for deciduous tree species at twelve locations and climate time series of air temperature (TMP, red and orange), precipitation (PCP, black), aridity index (dMI, green), and monthly tempera-

urban trees contain a useful climate signal and if it was possible to detect an UHI effect.

\section{Growth characteristics}

The different tree species exhibited similar growth rates when they were of the same age and grew under similar site conditions, as was shown for the eight tree species at GBS (Table $1 \&$ Fig. 4A). The analogous adaptation of the trees to their habitat (Schweingruber 1996; Schweingruber and Nogler 2003) can be used to explain the high similarity between growth series. This became even more clear in the detrended site chronologies after enhancing the highfrequency signal by suppressed long-term trends. Both the visual comparison of the chronologies and the computed chronology statistics that together describe the similarity between trees within and among sites were well above the threshold values indicating a strong common signal at local and regional scales. The overall comparison of rural and urban tree series revealed differences mainly concerning mean growth rates (Fig. 4B). However, the high-frequency growth reactions are similar (Fig. 4C), which indicates that in cities, apart from the age effect, additional growth factors such as pollution of air and soil (Eckstein and Krause 1989; Lundmark and Olofsson 2007), increased salinity (Cekstere et al. 2008; Cekstere and Osvalde 2013), sealed surfaces and compacted soils (Roberts et al. 2006; Helama et al. 2009), and increased likelihood of disturbance and injury (Grabosky and Gilman 2004; Roberts et al. 2006; ture range (MTR, blue) for June (squares), summer (JJA, diamonds) and extended summer (MJJA, triangles), and corresponding values of urbanity index UI determined for areal buffers with radii of $500 \mathrm{~m}$ (solid lines), $2000 \mathrm{~m}$ (dashed lines), and $2500 \mathrm{~m}$ (dotted lines) centered over the individual sampling sites

Bartens et al. 2012) may have a pronounced impact on absolute growth rates, but less so on the high-frequency sensitivity of trees. All site chronologies shared similar high-frequency variations despite the different growth levels and growth trends. This is a major reason for the fact that large climate reconstructions based on tree rings work so well when most trees grew similarly because they were affected by climate in similar ways (Cook et al. 2015).

The species-specific comparison of the mean growth rates demonstrated that urban trees were growing faster than rural trees (Fig. 4B), which can probably be explained by different mean ages of urban trees $(<100$ years old) and rural trees (>200 years old). However, Gregg et al. (2003) also found similar results for eastern cottonwood (Populus deltoids Bartr. ex Marsh) in New York City, USA, that grew twice as much plant biomass at urban than rural sites. Also, Pretzsch et al. (2017), who compared urban tree growth of metropolitan areas worldwide presented similar results. The authors concluded that, globally, in the last decades urban trees have been growing significantly faster than their rural counterparts, especially since around 1960 . However, the conclusion reached by Pretzsch et al. (2017) for Berlin lime trees differed from the overall global result, that is, the lime trees of Berlin, as one of the three metropole regions selected for the temperate zone in the study, grew more slowly in the city (Pretzsch et al. 2017). Gillner et al. (2013), on the other hand, found that sessile oak studied in Dresden, southeast of Berlin, grew faster in the city than in the surrounding rural area. Thus, the results of Pretzsch et al. (2017) concerning the slower growth of some 
of the Berlin city trees are somehow contradictory. Possibly, this could be due to the approach that different tree species were included in the urban-to-rural comparison (lime versus oak), despite the fact that different tree species adapt differently to varying site conditions (Schweingruber and Nogler 2003).

\section{Climate-growth response}

Climate-growth relationships of eight tree species growing together as a mixed stand and under relatively uniform climatic conditions provided ideal conditions for a comparative analysis of species-specific differences with regard to climatic influences in an urban setting. Two striking relationships were found for the Berlin trees, a winter signal comprising positive correlations between extended winter (December to March) temperature and tree-ring width of pine, and a summer signal characterized by the combination of negative temperature and positive precipitation correlations during extended summer (MJJA), and especially June. This combination of correlations was found for tree-ring widths of deciduous trees, in particular beech, oak and ash, but less so for lime. In addition, the combined summer signal translated into a strong correlation with the aridity index, dMI, similar to results obtained by Gillner et al. (2020) for oak in Potsdam. However, the strongest correlations of tree-ring width and climate was found with monthly averaged diurnal temperature range, MTR. The MTR parameter is already known in urban climatological studies as a good indicator for the description of the UHI (Varquez and Kanda 2018). At GBS $53 \%$ of the variance in the tree-ring width of the sessile oaks could be explained by June MTR, constituting a high value of determination for trees growing at the inner-city site.

While for dMI and MTR few comparative studies from European forest trees exist, the signals identified for temperature and precipitation are in good agreement with numerous studies based on forest trees in Central European regions. The winter signal of pine trees has already been demonstrated in northern Central Europe (van der Maaten et al. 2017; Koprowski et al. 2012), in the Baltic region (Elferts 2007; Pärn 2003), and western Germany (Friedrichs et al. 2009a; Fischer and Neuwirth 2012). It might be physiologically explained by the hypothesis that more warm days towards the end of winter, when the needles are not frozen anymore, result in an earlier shift towards a more positive carbon balance in the pines (Havranek and Tranquillini 1995). The summer signal of deciduous forests trees, especially oaks, has commonly been found in western (Friedrichs et al. 2009a, b) and eastern Germany (Bonn 1998; Gillner et al. 2014, 2020), in France (Lebourgeois et al. 2005), Czech Republic (Dobrovolný et al. 2016), and Sweden (Drobyshev et al. 2008). Scharnweber et al. (2011) identified a clearly increasing West-East gradient for the negative temperature signal in beech.
In contrast to the study by Dahlhausen et al. (2017) on 252 lime trees investigated in Berlin, which suggested that high temperatures with low precipitation would be beneficial for urban tree growth, our findings suggest the opposite. However, Dahlhausen et al. (2017) did not differentiate between seasons but only used annual temperature averages and annual sums of precipitation. In our study, lime showed the weakest climate signals of all hardwood species (yellow bars in Fig. 5). This, in turn, is a clear indication for its good suitability as a robust urban tree species, as it has also been classified previously as drought tolerant species with a strong hardiness (Roloff et al. 2009). When the climate data were aggregated into annual means, the annual correlation signals of the lime (yellow bars far right side of Fig. 5) in our study were negative for temperature and positive for precipitation. In combination, this resulted in positive correlations with dMI. However, all correlations between the annual mean of each climate parameter and lime tree-ring width remained non-significant.

Of particular interest for this study were correlations with climate during the summer because the UHI is most pronounced at this time of year (Hunt and Watkiss 2011; Fenner et al. 2014). The strong positive correlations with summer precipitation can be attributed to seasonal changes in water availability, whereas the negative correlations with summer temperature imply drought and heat stress. This inverse relationship was confirmed by dMI which exhibited slightly stronger correlations with treering width than with temperature or precipitation alone. In conclusion, urban trees grow better in summer under cool and wet conditions. The warmer it is, the greater the direct evaporation, which results in enhanced water stress for trees (Konarska et al. 2015).

Clear skies and sunny conditions in summer are usually associated with low relative humidity. During cloudless periods, daytime temperatures are high while nighttime temperatures can still drop resulting in a large diurnal temperature range. This might be the reason for the strong climate signals identified for MTR. The correlations with MTR were found to be stronger than the correlations with the other climate parameters. It is also conceivable that trees in a hot June and/ or extended summer actually suffer from direct heat stress during the day. It can be assumed that more water is transpired through the stomata of the leaves due to heat stress enhancing the water stress of trees.

Extreme weather events (e.g. heat waves without precipitation) usually affect large regions due to comparable overall synoptic conditions (Stefanon et al. 2012; Perkins 2015). Therefore, it can be expected that tree growth in the wider region should also be affected similarly. Hence, the results of climate-growth correlations using climate data of different weather stations in the region should be similar. This common signal might only be disturbed by particular local 
site characteristics and/or individual species-specific climate responses of the trees.

\section{Climate signals along an UHI gradient}

The strength of the climate-growth signal of the urban trees were found to be mainly affected by urban local-scale climatic conditions at radii of 500 to $3000 \mathrm{~m}$ around the individual study sites (Table 2; Fig. 6, the $200 \mathrm{~m}$ radii did not result in strong correlations). From this it can be concluded that for site chronologies averaged from at least twelve individual trees, the effect of the city (UHI) on tree growth is not only the result of the urban structures in the direct vicinity. For temperature-based parameters (TMP and MTR) the area of direct influence is smaller than for parameters that are also further determined by precipitation (PCP and $\mathrm{dMI}$ ), which rather reflect the urban climate at the scale of city quarters (1000 $\mathrm{m}$ to $2000 \mathrm{~m}$ radii). The climate-growth relationships thus tend to reflect a general local urban climatic influence. Before discussing the climatic signals in more detail, it should be noted that information on the provenances of the studied trees were not available. Therefore, the extent to which different provenances might have influenced climategrowth response (Opgenoorth et al. 2021; Yeaman et al. 2016) could not be investigated in our study.

The summer signal exhibited by the hardwood species was examined in more detail along a UHI gradient between rural and urban sites, with slightly stronger correlations to climate parameters being found for oak compared to beech and ash. Additionally, five rural and seven urban oak and ash sites with different degrees of urbanity were investigated. It could be demonstrated that with increasing urbanity, correlation strength with all climate parameters also intensified, indicated by positive or negative slopes of the regression (Fig. 7). The results are in line with the findings of Gillner et al. (2013) for northern red oak (Quercus rubra L.) growing at an urban site in Dresden, located about $165 \mathrm{~km}$ southeast of Berlin. There, correlations with June precipitation and temperature were stronger in comparison to the correlations at a rural forest site. This also indicates that the more urban the tree locations are the more heat stress the trees experienced, which in turn increases drought stress (Jacoby and D'Arrigo 1995). For sessile oak, on the other hand, Gillner et al. (2013) state an opposite trend, that is, the summer signals found at the urban site were much weaker than at the forest site. Gillner et al. (2013) explain this loss of signal by the relatively young age and other associated physiological reaction patterns of the urban sessile oak trees compared to those of the forest trees. However, it is questionable whether the different age can be the main reason for the diverse reactions since, e.g., Esper et al. (2008) imply that trees of different age and size classes still have similar climate signals. Additionally, by investigating tree rings from tulip trees (Liriodendron tulipifera L.) in southern Indiana,
USA, Wilde and Maxwell (2018) found that urban trees are more sensitive to climate impacts than their rural counterparts. By investigating Chinese pine (Pinus tabulaeformis Carr.) in Shenyang City, a city of about eight million people in northeast China, Chen et al. (2011) detected significant decreasing trends in the climate-growth correlations along a transect from rural to urban metropolitan areas. Further, the authors concluded that the decrease corresponded with increasing degrees of urbanity and industrialization. Their results are in contrast to increasing signal strength with increasing urbanity in our study. The reasons might be species-specific reactions in oak versus Chinese pine (Schweingruber 1996) and different impacts on local climate through the urban environments in Berlin and Shenyang City. According to Beck et al. (2018), the study by Chen et al. (2011) is located in the climate zone Dwa (,Köppen \& Geiger '), characterized by a cold-temperate climate with dry winters and humid summers (Kottek et al. 2006). It can therefore be concluded that our findings may not directly be transferable to other climate zones. For Berlin, however, there was a clear increase in climate signal strength along the rural-urban gradient where increasing urbanity could be identified, especially for June MTR.

Generally, the UHI is largely related to changes in the surface energy balance, especially through decreased evapotranspiration, anthropogenic heat release, radiation trapping of infrared radiation in canopies, and enhanced ground or storage heat flux (Oke 1982; Oke et al. 2017). In this respect, high sealing proportions lead to decreased water availability, reduced plant transpiration, and lowered latent heat flux (Christen and Vogt 2004). The resulting increase in Bowen ratio triggers near-surface warming through enhanced sensible heat flux, while sealed surfaces also enhance the storage heat flux during the day (Grimmond and Oke 1999). High building volumes allow for enhanced heat storage during the day, contributing to nighttime release of energy to the atmospheric canopy layer, thereby reducing nighttime cooling rates. High building volumes further act on reducing wind speed and directly contribute to the UHI by heat release from heating, air conditioning, process energy, and human metabolism.

The UI parameter combined building surface fraction (BF) and impervious surface fraction without buildings (ISF) to capture the main characteristics that contribute to the intensity of the UHI. Accordingly, the results lead to the conclusion that the temporal evolution of the strength of the climate-growth signal at a specific site may be indicative for the gradual development of the intensity of the UHI at this site. However, it must be emphasized that UI is not directly a measure of UHI, which is defined as the urban-rural temperature difference (Oke 1982). UI rather provides a more general indication of urban influences on local climate which, nonetheless, should substantially relate to UHI. Specifically, BF does directly relate to building volume, which would 
possibly be an even better proxy for the effects of buildings on the UHI. The urbanity effect determined based on the tree-growth to climate correlations and UI is weaker in the correlations between precipitation and temperature-related time series than in the correlations with the dryness index, which combines temperature and precipitation signals. Therefore, the urban effect, which is probably also to be interpreted as an UHI effect, is primarily acting as a summer drought stress for trees in urban areas.

\section{Conclusion}

The comparative study of eight tree species grown under similar regional climate conditions allowed for the first time to identify species-specific climate signals for urban trees in Berlin. A winter signal recorded in pine ring-width and a summer signal encoded in the growth of beech, oak, and ash tree-rings was found. Furthermore, for the summer signal a clear and high dependence of the signal strength on the degree of urbanity could be demonstrated for city hardwood species. The signal strength is so strong, at least between daily temperature range in June and May to July, that the degree of urbanity of further tree locations might be directly modeled from this relationship. This also offers the possibility to derive temporal changes of urbanity by considering moving time-window correlations in future studies. Depending on the climate variable, climate signals in the tree-ring chronologies were found to be representative for large areas implying that the urban influence on tree growth not only stems from the close urban vicinity of the trees, but rather reflects the urban climate at the scale of city quarters in the order of 0.8 to $12 \mathrm{~km}^{2}$ (500 to $2000 \mathrm{~m}$ radius). For the winter signal of pine, similar correlations patterns were identified across sites. However, since only one urban and one rural site were available these results need to be reevaluated in additional studies. In any case, these and planned subsequent studies provide a basis to model the UHI based on tree-ring parameters. Given that enough tree-ring data from various parts of the city are available, these proxies may allow delineating spatial and in particular temporal developments of the UHI in Berlin.

Acknowledgements We are grateful to Guido Fellhölter (district Berlin-Neukölln), Silvia Knöfel-Mosch, Klaus Pogrzeba and Thomas Koltermann (forestry office Köpenick) for granting official permits for coring tress.

Author contribution C.S. conceived the ideas and conceptual framework and organised paper writing. B.N. conceived the ideas, dated and measured tree-ring widths, contributed in conceptual framework, performed data analysis, and contributed in paper writing on dendroecological parts of the paper. S.S. performed tree-coring, took over major parts of the data analysis and design of figures, and structured the outline and draft of the manuscript. D.B. performed tree-coring, dated and measured tree-ring widths, assisted in data analysis, and contributed in paper writing on dendroecological parts of the paper. S.E. performed tree-coring, contributed in data collection, designing of figures as well as in paper writing. D.F. prepared the geographical information system (GIS) data of land use at the study sites (with F.M.) and contributed in designing of figures and paper writing. F.M. prepared the GIS data of land use at the study sites (with D.F.) and contributed in designing of figures and paper writing. I.H. contributed in data collection, data analysis as well as in paper writing.

Funding Open Access funding enabled and organized by Projekt DEAL. The authors would like to thank the DFG (German Research Foundation) for funding the project "Trees as Indicators of the Urban Heat Island" (grant No. SCHN 680/14-1). Daniel Fenner acknowledges funding by the DFG in the context of the research projects "Heatwaves in Berlin, Germany - urban climate modifications" (Grant No. SCHE 750/15-1) and "ENLIGHT" (Grant No. 437467569). We acknowledge support by the Open Access Publication Fund of Humboldt-Universität zu Berlin.

Availability of data and material Meteorological data of weather Station Berlin-Dahlem can be obtained from the German Weather Service (CDC - DWD Climate Data Center 2018). Raw tree-ring width measurement in this study can be found on the International Tree-Ring Data Bank.

\section{Declarations}

Conflict of interest The authors declare no conflict of interest. The funders had no role in the design of the study, in the collection, analyses, or interpretation of data, in the writing of the manuscript, or in the decision to publish the results.

Open Access This article is licensed under a Creative Commons Attribution 4.0 International License, which permits use, sharing, adaptation, distribution and reproduction in any medium or format, as long as you give appropriate credit to the original author(s) and the source, provide a link to the Creative Commons licence, and indicate if changes were made. The images or other third party material in this article are included in the article's Creative Commons licence, unless indicated otherwise in a credit line to the material. If material is not included in the article's Creative Commons licence and your intended use is not permitted by statutory regulation or exceeds the permitted use, you will need to obtain permission directly from the copyright holder. To view a copy of this licence, visit http://creativecommons.org/licenses/by/4.0/.

\section{References}

Ajaaj AA, Mishra AK, Khan AA (2018) Urban and peri-urban precipitation and air temperature trends in mega cities of the world using multiple trend analysis methods. Theor Appl Climatol 132:403-418. https://doi.org/10.1007/s00704-017-2096-7

Armson D, Rahman MA, Ennos AR (2013) A comparison of the shading effectiveness of five different street tree species in Manchester, UK. Arboricult Urban for 39:157-164

Arnfield AJ (2003) Two decades of urban climate research: a review of turbulence, exchange of energy and water, and the urban heat island. Int J Climatol 23:1-26. https://doi.org/10.1002/joc.859

Balanzategui D, Knorr A, Heussner KU, Wazny T, Beck W, Slowinski M, Helle G, Buras A, Wilmking M, Van Der Maaten E, Scharnweber T, Dorado-Liñán I, Heinrich I (2018) An 810-year history of cold season 
temperature variability for northern Poland. Boreas 47(2):443-453. https://doi.org/10.1111/bor.12274

Bartens J, Grissino-Meyer HD, Day SD, Wiseman PE (2012) Evaluating the potential for dendrochronological analysis of live oak (Quercus virginiana Mill.) from the urban and rural environment - an explorative study. Dendrochronologia 30:15-21. https://doi.org/10.1016/j. dendro.2011.04.002

Bayer D, Reischl A, Rötzer T, Pretzsch H (2018) Structural response of black locust (Robinia pseudoacacia L.) and small leaved lime (Tilia cordata Mill.) to varying urban environments analyzed by terrestrial laser scanning: Implications for ecological functions and services. Urban for Urban Green 35:129-138

Beck HE, Zimmermann NE, McVicar TR, Vergopolan N, Berg A, Wood EF (2018) Present and future Köppen-Geiger climate classification maps at 1-km resolution. Sci Data 5:180214. https:// doi.org/10.1038/sdata.2018.214

Berland A, Shiflett SA, Shuster WD, Garmestani AS, Goddard HC, Herrmann DL, Hopton ME (2017) The role of trees in urban stormwater management. Landsc Urban Plan 162:167-177

Bonn S (1998) Dendroökologische Untersuchung der Konkurrenzdynamik in Buchen/ Eichen-Mischbeständen und zu erwartende Modifikationen durch Klimaänderungen. In: Forstwissenschaftliche Beiträge Tharandt/Contributions to Forest Sciences 3, Tharandt, p 226

Broadbent AM, Coutts AM, Nice KA, Demuzere M, Krayenhoff ES, Tapper NJ, Wouters H (2019) The air-temperature response to green/blue-infrastructure evaluation tool (TARGET v1. 0): an efficient and user-friendly model of city cooling. Geosci Model Dev 12:785-803

Buccolieri R, Santiago JL, Rivas E, Sanchez B (2018) Review on urban tree modelling in CFD simulations: aerodynamic, deposition and thermal effects. Urban for Urban Green 31:212-220

Buttstädt M, Schneider C (2014) Thermal load in a medium-sized European city using the example of Aachen. Germany Erdkunde 68(2):71-83. https://doi.org/10.3112/erdkunde.2014.02.01

Canetti A, de Mattos PP, Braz EM, Netto SP (2017) Life pattern of urban trees: a growth-modelling approach. Urban Ecosyst 20:1057-1068

CDC - DWD Climate Data Center (2018) Historische tägliche Stationsbeobachtungen (Temperatur, Druck, Niederschlag, Sonnenscheindauer, etc.) für Deutschland, Version v006; ftp://ftp-cdc. dwd.de/pub/CDC/observations_germany/climate. Accessed 4 Apr 2021

Cedro A (2007) Rolawskaznika NAO w kształtowaniu przyrostow rocznych sosny zwyczajnej. In K Piotrowicz, and R Twardosz (Eds.), Wahania Klimatu w Roz_nych Skalach Przestrzennych i Czasowych, 323-330. Instytut Geografii i Gospodarki Przestrzennej Uniwersytet Jagiellonski, Krakow

Cekstere G, Nikodemus O, Osvalde A (2008) Toxic impact of the deicing material to street greenery in Riga. Latvia Urban for Urban Green 7(3):207-2017. https://doi.org/10.1016/j.ufug.2008.02.004

Cekstere G, Osvalde A (2013) A study of chemical characteristics of soil in relation to street trees status in Riga (Latvia). Urban for Urban Green 12(1):69-78. https://doi.org/10.1016/j.ufug.2012. 09.004

Chapman L, Bell C, Bell S (2017) Can the crowdsourcing data paradigm take atmospheric science to a new level? A case study of the urban heat island of London quantified using Netatmo weather stations. Int J Climatol 37(9):3597-3605. https://doi.org/ 10.1002/joc.4940

Chen Z, He X, Cui M, Davi N, Zhang X, Chen W, Sun Y (2011) The effect of anthropogenic activities on the reduction of urban tree sensitivity to climatic change: Dendrochronological evidence from Chinese pine in Shenyang city. Trees 25(3):393-405
Christen A, Vogt R (2004) Energy and radiation balance of a central European city. Int J Climatol 24(11):1395-1421. https://doi.org/ 10.1002/joc. 1074

Cook ER (1985) A time series approach to tree-ring standardization. University of Arizona, PhD-Thesis

Cook ER, Kairiukstis LA (1990) Methods of dendrochronology applications in the environmental sciences. Springer, Netherlands, Dordrecht

Cook ER, Seager R, Kushnir Y, Briffa KR, Büntgen U, Frank D, Krusic PJ, Tegel W, van der Schrier G, AndreuHeyles L, Bailie M, Baittinger C, Bleicher N, Bonde N, Brown D, Carrer M, Cooper R, Cufar K, Dittmar C, Esper GC, Gunnarson B, Günther B, Gutierrez E, Haneca K, Helama S, Herzig F, Heussner KU, Hofmann J, Janda P, Kontic R, Köse N, Kyncl T, Levanic T, Linderholm H, Manning S, Melvin TM, Miles D, Neuwirth B, Nicolussi K, Nola P, Panayotov M, Popa I, Rothe A, Seftigen K, Seim A, Svarva H, Svoboda M, Thun T, Timonen M, Touchan R, Trotsiuk V, Trouet V, Walder F, Wazny T, Wilson R, Zang C (2015) Old world megadroughts and pluvials during the common era. Sci Adv 1(10):e150061. https://doi. org/10.1126/sciadv.1500561

Cubasch U, Kadow C (2011) Global climate change and aspects of regional climate change in the Berlin-Brandenburg region. Erde 142(1/2):3-20

Dahlhausen J, Rötzer T, Biber P, Uhl E, Pretzsch H (2017) Urban climate modifies tree growth in Berlin. Int J Biometeorol 62:795808. https://doi.org/10.1007/s00484-017-1481-3

De Martonne E (1926) Une nouvelle fonction climatologique: L'indice d'aridité. La Météorologie 2:449-458

Dobrovolný P, Rybnícek M, Büntgen U, Trnka M, Brázdil R, Stachon Z, Prokop O, Kolár T (2016) Recent growth coherence in longterm oak (Quercus spp.) ring width chronologies in the Czech Republic. Clim Res 70(2-3):133-141. https://doi.org/10.3354/ cr01402

Drobyshev I, Niklasson M, Eggertsson O, Linderson H, Sonesson K (2008) Influence of annual weather on growth of pedunculate oak in southern Sweden. Ann For Sci 65:512-512p14. https:// doi.org/10.1051/forest:2008033

DWD (2019) Wetterlexikon. Klimatologische Normalperiode. Deutscher Wetterdienst. https://www.dwd.de/DE/service/ lexikon/Functions/glossar.html?1v2=101334\&lv3=101454. Accessed 21 Jun 2021

Eckstein D, Dujesiefken D (1999) Long-term effects in trees due to increment borings. Dendrochronologia 16-17:205-211

Eckstein D, Krause C (1989) Dendroecological studies on spruce trees to monitor environmental changes around Hamburg. IAWA J 10(2):175-182. https://doi.org/10.1163/22941932-90000486

Elferts D (2007) Scots pine pointer years in northwestern Latvia and their relationship with climate factors. Acta Universitatis Latviensis 723:163-170

Environmental Atlas Berlin (2020) Berlin Senate Department for Urban Development and the Environment. https://www.berlin. de/umweltatlas/en/general/imprint. Accessed 24 Oct 2020

Escobedo FJ, Kroeger T, Wagner JE (2011) Urban forests and pollution mitigation: analyzing ecosystem services and disservices. Environ Pollut 159:2078-2087

Esper J, Neuwirth B, Treydte K (2001) A new parameter to evaluate temporal signal strength of tree-ring chronologies. Dendrochronologia 19(1):93-102

Esper J, Niederer R, Bebi P, Frank D (2008) Climate signal age effects-evidence from young and old trees in the Swiss Engadin. For Ecol Manage 255(11):3783-3789. https://doi.org/10. 1016/j.foreco.2008.03.015

Feichtinger M, de Wit R, Goldenits G, Kolejka T, Hollósi B, ŽuvelaAloise M, Feigl J (2020) Case-study of neighborhood-scale summertime urban air temperature for the City of Vienna using 
crowd-sourced data. Urban Climate 32:100597. https://doi.org/ 10.1016/j.uclim.2020.100597

Fenner D, Meier F, Scherer D, Polze A (2014) Spatial and temporal air temperature variability in Berlin, Germany, during the years 2001-2010. Urban Climate. https://doi.org/10.1016/j.uclim. 2014.02.004

Fenner D, Meier F, Bechtel B, Otto M, Scherer D (2017) Intra and inter 'local climate zone' variability of air temperature as observed by crowd sourced citizen weather stations in Berlin. Germany Meteorol Z 26(5):525-547. https://doi.org/10.1127/metz/2017/0861

Finley K, Chhin S, Nzokou P (2016) Effects of climate on the radial growth of white ash infested with emerald ash borer. For Ecol Manag 379:133-145

Fischer S, Neuwirth B (2012) Climate sensitivity of Douglas-fir in Eifel and Kellerwald. Allg for Jagdztg 183(1):23-33

Fischer S, Neuwirth B (2013) Vulnerability of trees to climate events in temperate forests of West Germany. ISRN for 2013:15p. https:// doi.org/10.1155/2013/201360

Friedrichs DA, Trouet V, Büntgen U, Frank DC, Esper J, Neuwirth B, Löffler J (2009a) Species-specific climate sensitivity of tree growth in Central-West Germany. Trees 23(4):729-739. https:// doi.org/10.1007/s00468-009-0315-2

Friedrichs DA, Büntgen U, Frank DC, Esper J, Neuwirth B, Löffler J (2009b) Complex climate controls on 20th century oak growth in Central-West Germany. Tree Physiol 29(1):39-51. https://doi. org/10.1093/treephys/tpn003

Fritts HC (1976) Tree rings and climate. Academic Press, London

Früh B, Becker P, Deutschländer T, Hessel JD, Kossmann M, Mieskes I, Namyslo J, Roos M, Sievers U, Steigerwald T, Turau H, Weinert U (2011) Estimation of climate-change impacts on the urban heat load using an urban climate model and regional climate projections. J Appl Meteorol Clim 50:167-184. https:// doi.org/10.1175/2010JAMC2377.1

Gebert LL, Coutts AM, Tapper NJ (2019) The influence of urban canyon microclimate and contrasting photoperiod on the physiological response of street trees and the potential benefits of water sensitive urban design. Urban for Urban Green 40:152-164

Gillner S (2012) Stadtbäume im Klimawandel - Dendrochronologische und physiologische Untersuchungen zur Identifikation der Trockenstressempfindlichkeit häufig verwendeter Stadtbaumarten in Dresden. Dissertation, TU Dresden

Gillner S, Vogt J, Roloff A (2013) Climate response and impacts of drought on oaks at urban and forest sites. Urban for Urban Green 12(4):597-605. https://doi.org/10.1016/j.ufug.2013.05.003

Gillner S, Bräuning A, Roloff A (2014) Dendrochronological analysis of urban trees: climatic response and impact of drought on frequently used tree species. Trees 28(4):1079-1093. https://doi. org/10.1007/s00468-014-1019-9

Gillner S, Vogt J, Tharang A, Dettmann S, Roloff A (2015) Role of street trees in mitigating effects of heat and drought at highly sealed urban sites. Landsc Urban Plan 143:33-42

Gillner S, Fenner D, Bräuning A, Rohde M, Roloff A, Seliger A, Schmidt-Wiegand A Kühn N (2020) Response of growth to climate within Oaks of the World Heritage Site of Prussian Gardens. Int J Forestry and Hortic 6(2):1-15. https://doi.org/10. 20431/2454-9487.0602001

Grabosky J, Gilman E (2004) Measurement and prediction of tree growth reduction from tree planting space design in established parking lots. J Arboriculture 30(3):154-164

Gregg JW, Jones CG, Dawson TE (2003) Urbanization effects on tree growth in the vicinity of New York City. Nature 424:183-187. https://doi.org/10.1038/nature01728

Grimmond CSB, Oke TR (1999) Heat storage in urban areas: Local scale observations and evaluation of a simple model. J Appl Meteo 38(7):922-940. https://doi.org/10.1175/1520-0450(1999) 038\%3c0922:HSIUAL\%3e2.0.CO;2
Grote R, Samson R, Alonso R, Amorim JH, Cariñanos P, Churkina G, Fares S, Thiec DL, Niinemets Ü, Mikkelsen TN, Paoletti E, Tiwary A, Calfapietra C (2016) Functional traits of urban trees: Air pollution mitigation potential. Front Ecol Environ 14:543-550

Harvey JE, Smiljanić M, Scharnweber T, Buras A, Cedro A, CruzGarcía R, Drobyshev I, Janecka K, Jansons Ā, Kaczka R, Klisz M (2020) Tree growth influenced by warming winter climate and summer moisture availability in northern temperate forests. Glob Change Bio 26(4):2505-2518

Havranek M, Tranquillini W (1995) Physiological processes during their winter dormancy and their ecological significance. In: Smith WK, Hinkley TM (eds) Ecophysiology of coniferous forests. Academic Press, New York, pp 95-124

Helama S, Läänelaid A, Raisio J, Tuomenvirta H (2009) Oak decline in Helsinki portrayed by tree-rings, climate and soil data. Plant Soil 319(1):163-174. https://doi.org/10.1007/ s11104-008-9858-z

Holmes RL (1983) Computer-assisted quality control in tree-ring dating and measurement. Tree-Ring Bull 43:69-78

Howard L (1833) The climate of London. Deduced from Meteorological Observations made in the metropolis and various places around it. Longman and Co. London

Hunt A, Watkiss P (2011) Climate change impacts and adaptation in cities: a review of the literature. Clim Change 104(1):13-49. https://doi.org/10.1007/s10584-010-9975-6

Jacoby GC, D'Arrigo RD (1995) Tree ring width and density evidence of climatic and potential forest change in Alaska. AGU 9(2):227234. https://doi.org/10.1029/95GB00321

Konarska J, Uddling J, Holmer B, Lutz M, Lindberg F, Pleijel H, Thorsson S (2015) Transpiration of urban trees and its cooling effect in a high latitude city. Int J Biometerol 60:159-172. https:// doi.org/10.1007/s00484-015-1014-x

Koprowski M, Przybylak R, Zielski A, Pospieszyńska A (2012) Tree rings of Scots pine (Pinus sylvestris $\mathrm{L}$.) as a source of information about past climate in northern Poland. Int J Biometeorol 56:1-10. https://doi.org/10.1007/s00484-010-0390-5

Kottek M, Grieser J, Beck C, Rudolf B, Rubel F (2006) World Map of the Köppen-Geiger climate classification updated. Meterologische Z 5(3):259-263. https://doi.org/10.1127/0941-2948/2006/ 0130

Kuttler W (2004) Stadtklima. Teil 1: Grundzüge und Ursachen. In: Beitragsserie: Klimaänderung und Klimaschutz.https://www.unidue. de/imperia/md/content/geographie/klimatologie/kuttler2004a.pdf. Accessed 22 Jun 2021

Kuttler W, Miethke A, Dütemeyer D, Barlaf AB (2015) Das Klima von Essen/ The Climate of Essen. WestarpWissenschaften, Hohenwarsleben

Lebourgeois F, Breda N, Ulrich E, Granier A (2005) Climate-treegrowth relationships of European beech (Fagus sylvatica L.) in the French Permanent Plot Network (RENECOFOR). Trees 19(4):385-401. https://doi.org/10.1007/s00468-004-0397-9

Locosselli GM, de Camargo EP, Moreira TCL, Todesco E, de Fátima AM, de André CDS, de André PA, Singer JM, Ferreira LS, Saldiva PHN, Buckeridge MS (2019) The role of air pollution and climate on the growth of urban trees. Sci Total Environ 666:652-661

Lundmark A, Olofsson B (2007) Cloride deposition and distribution in soils along a deiced highway - assessment using different methods of measurements. Water Air Soil Pollut 182:173-185. https:// doi.org/10.1007/s11270-006-9330-8

Matzarakis A (2001) Die thermische Komponente des Stadtklimas. In: Berichte des Meteorologischen Institutes der Universität Freiburg 6:286

McCarroll D, Loader NJ (2004) Stable isotopes in tree rings. Quatern Sci Rev 23:771-801 
Meier F, Fenner D, Grassmann T, Otto M, Scherer D (2017) Crowdsourcing air temperature from citizen weather stations for urban climate research. Urban Climate 19:170-191. https://doi.org/10. 1016/j.uclim.2017.01.006

Moir AK (2008) The dendroclimatology of Modern and Neolithic Scots pine (Pinus sylvestris L.) in the peatlands of northern Scotland. Ph.D. Thesis, Brunel University, pp 270

Moser-Reischl A, Rahman MA, Pauleit S, Pretzsch H, Rötzer T (2019a) Growth patterns and effects of urban micro-climate on two physiologically contrasting urban tree species. Landsc Urban Plan 183:88-99

Moser-Reischl A, Rötzer T, Biber P, Ulbricht M, Uhl E, Qu L, Koike T, Pretzsch H (2019b) Growth of Abies sachalinensis along an urban gradient affected by environmental pollution in Sapporo. Japan for 10:707

Müller-Westermeier G (1999) Die mittleren klimatologischen Bedingungen in Deutschland (Teil III). Deutscher Wetterdienst. https://www. dwd.de/DE/leistungen/klimastatusbericht/publikationen/ksb1999_ pdf/07_1999.pdf?_blob=publicationFile\&v=1. Accessed 24 Jun 2021

Oke TR (1982) The energeticbasisofthe urban heatisland. Q J R Meteorol Soc 108(455):1-24. https://doi.org/10.1002/qj.49710845502

Oke TR, Mills G, ChristenA VJA (2017) Urban climates. Cambridge Univ. Press, Cambridge

Opała M (2015) The 443-year tree-ring chronology for the Scots pine from Upper Silesia (Poland) as a dating tool and climate proxy. Geochronometria 42(1):41-52

Opgenoorth L, Dauphin B, Benavides R, 116 further authors (2021) The GenTree Platform: Growth traits and tree-level environmental data in 12 European forest tree species. Giga Sci 10. https://doi.org/10. 1093/gigascience/giab010

Pärn H (2003) Radial growth response of Scots pine to climate under dust pollution in northeast Estonia. Water Air Soil Pollut 144(1/4):343-361

Perkins SE (2015) A review on the scientific understanding of heat waves - Their measurement, driving mechanisms, and changes at the global scale. Atmos Res 164-165:242-267. https://doi.org/10. 1016/j.atmosres.2015.05.014

Pretzsch H, Biber P, Uhl E, Dahlhausen J, Schütze G, Perkins D, Rötzer T, Caldentey J, Koike T, Van Con T, Chavenne A, Du Toit B, Foster $\mathrm{K}$, Lefer B (2017) Climate change accelerates growth of urban trees in metropolises worldwide. Sci Rep 7:15403. https://doi.org/10. 1038/s41598-017-14831-w

Przybylak R, Majorowicz J, Wójcik G, Zielski A, Chorazyczewski W, Marciniak K, Nowosad W, Olinski N, Syta K (2005) Temperature changes in Poland from the 16th to the 20th centuries. Int J Climatol 25:773-791. https://doi.org/10.1002/joc.1149

Rahman MA, Hartmann C, Moser-Reischl A, von Strachwitz MF, Paeth H, Pretzsch H, Pauleit S, Rötzer T (2020) Tree cooling effects and human thermal comfort under contrasting species and sites. Agric For Meteorol 287:107947

Rinn F (2005) TSAP-WinTM. Time Series Analysis and Presentation for Dendrochronology and Related Applications. Version 4.6. Heidelberg

Roberts J, Jackson N, Smith M (2006) Tree roots in the built environment. The Stationary Office, Norwich

Rötzer T, Rahman MA, Moser-Reischl A, Pauleit S, Pretzsch H (2019) Process based simulation of tree growth and ecosystem services of urban trees under present and future climate conditions. Sci Total Environ 676:651-664

Roloff A, Korn S, Gillner S (2009) The Climate-Species-Matrix to select tree species for urban habitats considering climate change. Urban for Urban Green 8(4):295-308. https://doi.org/10.1016/j.ufug.2009. 08.002

Scharnweber T, Manthey M, Criegee C, Bauwe A, Schröder C, Wilmking M (2011) Drought matters - Declining precipitation influences growth of Fagus sylvatica L. and Quercus robur L. in north-eastern Germany. For Ecol Manage 262(6):947-961. https://doi.org/10.1016/j.foreco.2011.05.026

Scharnweber T, Heußner KU, Smiljanic M, Heinrich I, van der MaatenTheunissen M, van der Maaten E, Struwe T, Buras A, Wilmking M (2019) Removing the no-analogue bias in modern accelerated tree growth leads to stronger medieval drought. Sci Rep 9:2509. https:// doi.org/10.1038/s41598-019-39040-5

Schubert S, Grossmann-Clake S, Martille A (2012) A double-canyon radiation scheme for multi-layer urban canopy models. Boundary Layer Meteorol 145:439-468. https://doi.org/10.1007/ s10546-012-9728-3

Schuldt B, Buras A, Arend M, Vitasse Y, Beierkuhnlein C, Damm A, Gharung M, Gramsh TEE, Hauck M, Hajek P, Hartmann H, Hiltbrunner E, Hoch G, Holloway-Phillips M, Körner C, Larysch E, Lübbe T, Nelson DB, Rammig A, Rigling A, Rose L, Ruehr RK, Schumann K, Weiser F, Werner C, Wohlgemuth T, Zang CS, Kahmen A (2020) A first assessment of the impact of the extreme 2018 summer drought on Central European forests. Basic Appl Ecol 45:86-103. https://doi.org/10.1016/j.baae.2020.04.003

Schweingruber FH (1996) Tree rings and environment - Dendroecology. Paul Haupt, Berne

Schweingruber FH, Nogler P (2003) Synopsis and climatological interpretation of Central European tree-ring sequences. Bot Helv 113(2):125-143. https://doi.org/10.5169/seals-137558

SEN (Senatsverwaltung für Umwelt, Verkehr und Klimaschutz Berlin, Referat Freiraumplanung und Stadtgrün) (2017) Straßenbäume in Berlin. Grünflächeninformationssystem (GRIS). https://www. berlin.de/senuvk/umwelt/stadtgruen/stadtbaeume/de/daten_fakten/ downloads/ausw_75.pdf. Accessed 23 Jun 2021

Smithers RJ, Doick KJ, Burton A, Sibille R, Steinbach D, Harris R, Groves L, Blicharska M (2018) Comparing the relative abilities of tree species to cool the urban environment. Urban Ecosyst 21:851862. https://doi.org/10.1007/s11252-018-0761-y

Speer JH (2010) Fundamentals of tree-ring research. The University of Arizona Press, USA

Stefanon M, D’Andrea F, Drobinski P (2012) Heatwave classification over Europe and the Mediterranean region. Environ Res Lett 7(1):014023. https://doi.org/10.1088/1748-9326/7/1/014023

Stokes MA, Smiley TL (1968) An introduction to tree-ring dating. The University of Chicago Press, Chicago

Stratopoulos LMF, Zhang C, Häberle KH, Pauleit S, Duthweiler S, Pretzsch H, Rötzer T (2019) Effects of drought on the phenology, growth, and morphological development of three urban tree species and cultivars. Sustainability 11:5117

Van der Maaten E, Mehl A, Wilmking M, von der Maaten M (2017) Tapping the tree-ring archive for studying effects of resin extraction on the growth and climate sensitivity of Scots pine. For Ecosyst 4:7.https://doi.org/10.1186/s40663-0096-9

Varquez CG, Kanda M (2018) Global urban climatology: a meta-analysis of air temperature trends (1960-2009). NPJ Climate Atmos Sci 1(32). https://doi.org/10.1038/s41612-018-0042-8

Venter ZS, Brousse O, Esau I, Meier F (2020) Hyperlocal mapping of urban air temperature using remote sensing and crowdsourced weather data. Remote Sens Environ 242:111791. https://doi.org/ 10.1016/j.rse.2020.111791

Wigley TML, Briffa KR, Jones PD (1984) On the average value of correlated time series, with applications in dendroclimatology and 
hydrometeorology. J Clim Appl Meteorol 23(2):201-213. https:// doi.org/10.1175/1520-0450(1984)023\%3c0201:OTAVOC\%3e2.0. $\mathrm{CO} ; 2$

Wilde EM, Maxwell JT (2018) Comparing climate-growth responses of urban and non-urban forests using L. tulipifera tree-rings in southern Indiana, USA. Urban for Urban Green 31:103-108
Yeaman S, Hodgins KA, Lotterhos KE, Suren H, Nadeau S, Degner JC, Nurkowski KA, Smets P, Wang T, Gray LK, Liepe KJ, Hamann A, Holliday JA, Whitlock MC, Rieseberg LH, Aitken SN (2016) Convergent local adaptation to climate in distantly related conifers. Science 353:1431-1433 